\title{
LEMBAR KERJA PESERTA DIDIK (LKPD) PENGEMBANGAN SEBAGAI SARANA PENINGKATAN KETERAMPILAN PROSES PEMBELAJARAN IPA DI SMP
}

\author{
EVY ALDIYAH \\ Guru IPA SMP Negeri 202 Jakarta \\ evyaldy@gmail.com
}

\begin{abstract}
ABSTRAK
Untuk membangkitkan minat belajar dan peningkatan keterampilan proses peserta didik salah satunya dengan memanfaatkan Lembar Kerja Peserta Didik (LKPD) yang dikembangkan atau dirancang sendiri oleh guru. Pengembangan atau perancangan LKPD tersebut dapat dibuat berdasarkan kondisi sekolah dan lingkungan. Literature review ini bertujuan untuk menganalisa beberapa artikel terhadap peningkatan keterampilan proses peserta didik dengan menggunakan LKPD yang dikembangkan atau dirancang sendiri oleh guru dan memberikan kontribusi keilmuan di masa mendatang tentang teknik pengembangan LKPD. Desain yang digunakan adalah literature review, dengan langkah awal formulasi masalah dilanjutkan dengan pencarian literatur, evaluasi data dan menganalisis literatur. Sehingga didapatkan 8 artikel sampel yang terbit pada rentang waktu bulan Januari 2019 sampai dengan Desember 2020. Dari 8 artikel yang direview tampak persamaan pada tujuan penelitian dan hasil yang dicapai. Perbedaan hanya tampak pada metode dan teknik yang digunakan serta keragaman metode pembelajaran yang digunakan dalam kegiatan pembelajarannya. Pengembangan model ADDIE (Analysis, Design, Development, Implementation, Evaluation), dan model 4D (Define, Design, Develop, Disseminate) banyak digunakan dalam penelitian pengembangan LKPD. Pemilihan metode pembelajaran dalam kegiatan pembelajarannya juga sangat mendukung hasil yang dicapai, LKPD yang dikembangkan benar-benar membangkitkan minat belajar peserta didik serta meningkatkan keterampilan proses peserta didiknya. Secara umum semua artikel penelitian pengembangan LKPD yang direview adalah dalam katagori sangat baik, tergolong layak dan valid serta dapat menjadi bahan acuan bagi guru yang ingin melakukan pengembangan LKPD guna meningkatkan aktifitas dan keterampilan proses peserta didik.
\end{abstract}

Kata kunci : LKPD pengembangan, pembelajaran IPA, keterampilan proses

\section{PENDAHULUAN}

Proses pembelajaran merupakan penentu dari proses pendidikan di sekolah. Keberhasilan atau tercapainya tujuan pembelajaran sangat dipengaruhi oleh proses pembelajaran yang dialami oleh peserta didik (Nurmahudina, Distrik, \& Wahyudi, 2019). Salah satu mata pelajaran penting yang diberikan pada pembelajaran di tingkat SMP adalah Ilmu Pengetahuan Alam, dimana pembelajaran yang dilakukan tidak cukup hanya dengan menyimak teori-teori dan konsep-konsep yang disampaikan guru, melainkan lebih kepada pemahaman melalui pengamatan dan penemuan yang 
memberikan pengalaman langsung untuk mengembangkan kompetensi dan kreatifitasnya.

Pemerintah melalui Kurikulum 2013 menetapkan pembelajaran IPA dikembangkan berbasis pendekatan scientific dimana penekanan lebih kepada proses ilmiah, dimana guru berperan sebagai pembimbing, fasilisator dan pendamping peserta didik sehingga guru diharapkan mampu untuk merancang pembelajaran yang lebih efektif (Kemendikbud, 2013). Dalam Permendikbud Nomor 65 Tahun 2013 dijelaskan bahwa pembelajaran IPA berorientasi pada 3 ranah kompetensi yaitu, sikap, pengetahuan dan keterampilan. Keterampilan proses sains (KPS) merupakan keterampilan yang mendasar yang harus dimiliki oleh peserta didik (Kemendikbud, 2013). Diungkapkan oleh Sirajudin, et al (2018) dalam Wulandari, Widiyawati, \& Sari (2020), pentingnya KPS dalam proses pembelajaran yaitu untuk mengembangkan ilmu pendidikan serta kualitas belajar peserta didik baik itu teori maupun keterampilan bereksperimen.

Untuk pemenuhan tuntutan tersebut telah banyak yang telah diupayakan, antara lain menggunakan bahan ajar yang memuat keterampilan berpikir kreatif yang dibutuhkan sebagai fasilitas dalam mengeksplorasi potensi pengetahuan dan keterampilan peserta didik. Pengembangan pembuatan Lembar Kerja Peserta Didik (LKPD) adalah salah satu upaya tersebut. Diharapkan peserta didik dapat mengembangkan pengetahuan dan keterampilannya melalui pembelajaran menggunakan LKPD.

Semua kegiatan mendasar yang harus dilakukan peserta didik terkumpul dalam LKPD untuk memaksimalkan pemahamann dan pembentukan kemampuan dasar sesuai dengan indikator pencapaian kompetensinya, seperti yang dikemukakan oleh Trianto (2009) dalam Riadi, M (2015). Namun pada kenyataanya LKPD yang banyak digunakan di sekolah bersifat umum karena berisi ringkasan materi saja dan soal-soal sehingga berdampak kurang tertarik dan rasa malas peserta didik karena kegiatannya bersifat monoton dan cenderung hanya menghafal konsep. Jadi LKPD yang digunakan seakan menjadi tidak efektif karena hanya memuat rangkuman materi, soal objektif dan soal uraian, yang semakin membuat peserta didik malas dan kurang tertarik. Aktifitas peserta didik dalam pembelajaran belum berkembang secara maksimal.

Untuk membangkitkan minat belajar peserta didik salah satunya dengan memanfaatkan LKPD yang dikembangkan atau dirancang sendiri oleh guru dimana pengembangan atau perancangan LKPD tersebut dapat dibuat berdasarkan kondisi sekolah dan lingkungan (Oktricia, Yani, \& Ansori, 2019). LKPD yang dirancang atau yang dikembangkan tidak hanya menilai kemampuan kognitif saja tetapi diharapkan juga mampu mengkolaborasikan aktivitas fisik peserta didik dalam memahami konsep materi eksperimen maupun non-eksperimen (Syafi' ah \& Laili, 2020). Guru diharapkan mampu mengembangkan atau merancang LKPD sesuai dengan prosedur pembuatan LKPD, dimana ada 3 persyaratan dalam pengembangan LKPD yaitu syarat didaktik, syarat konstruksi dan syarat teknis , sebagaimana yang dikemukakan oleh Darmojo \& Kaligis (1993) dalam Riadi, M (2015). Sehingga diharapkan pembelajaran menjadi lebih bermakna dengan LKPD yang dirancang sendiri oleh guru sebagai alat bantunya yang disesuaikan dengan kondisi dan lingkungan peserta didik (Oktricia, et al, 2019). 
Manfaat LKPD dikemukakan oleh Suyitno (1997) dalam Riadi, M (2015) yaitu 1) Peserta didik menjadi aktif dalam kegiatan pembelajaran, 2) Peserta didik terbantu dalam mengembangkan konsep, 3) Peserta didik berlatih mengembangkan keterampilan prosesnya, 4) Menjadi pedoman guru dan peserta didik dalam kegiatan pembelajaran, 5) Peserta didik terbantu dalam menerima materi dan informasi secara sistematis tentang konsep yang dipelajari.

Tujuan literature review ini adalah : (1) Menganalisa beberapa artikel terhadap peningkatan keterampilan proses peserta didik dengan menggunakan LKPD yang dikembangkan atau dirancang sendiri oleh guru. (2) Memberikan kontribusi keilmuan di masa mendatang tentang teknik pengembangan LKPD. Sedangkan manfaat yang diharapkan adalah mengetahui beberapa bentuk metode pengembangan LKPD terkini yang dikembangkan atau dirancang oleh guru dan diharapkan mampu menginspirasi bagi guru lain dalam penerapan LKPD dalam pembelajaran di kelasnya.

\section{METODE PENELITIAN}

\section{A.Desain Penelitian}

Desain penelitian ini adalah Literature Review. Literature review merupakan analisa kritis dari penelitian yang sedang dialakukan terhadap topik khusus., seperti yang dikemukakan oleh Agusta, Yudi (2007) dalam Syafridawati (2020). Shutlleworth (2009) juga dalam Syafridawati (2020), Literature review is a critical and in depth evaluation of previous research. Jadi Litetrature review bukan hanya bermakna membaca literatur, tetapi lebih mendalam lagi serta kritis terhadap penelitian sebelumnya yang sesuai dengan topik.

\section{B. Kriteria Inklusi dan Eksklusi}

1. Tipe Studi : Tipe studi yang digunakan adalah analisis komparasi. Studi analisis komparasi adalah riset yang bersifat membandingkan, dimana variabel sampelnya mandiri dan lebih dari satu dalam waktu yang berbeda.

2. Tipe Intervensi : Intervensi utama yang ditelah pada penelusuran ilmiah ini adalah bentuk teknik LKPD yang digunakan dalam pembelajaran IPA di SMP dan hubungannya dengan dengan hasil yang dicapai.

3. Hasil Ukur : Hasil ukur dalam penelusuran ilmiah ini adalah hubungan bentuk teknik LKPD yang digunakan dalam pembelajaran IPA di SMP dengan hasil yang dicapai.

4. Strategi Pencarian Literatur : Penelusuran artikel publikasi pada google search dan google scholar menggunakan kata kunci yang dipilih yakni : pengembangan LKPD, pembelajaran IPA, dan keterampilan proses. Artikel yang sesuai dengan kriteria inklusi dan eksklusi diambil untuk selanjutnya dianalisis. Literature Review ini menggunakan literatur terbitan tahun 2019-2020 yang dapat diakses fulltext dalam format pdf. Kriteria artikel yang direview adalah artikel dalam jurnal penelitian berbahasa Indonesia dengan subyek LKPD, jenis artikel penelitian bukan literature review dengan tema Pengembangan LKPD di SMP. 
Adapun kritera inklusi penelitian dapat dilihat pada tabel 1 berikut :

Tabel 1. Kriteria Inklusi Kriteria Inklusi

\begin{tabular}{|l|l|}
\hline \multicolumn{1}{|c|}{ Kriteria } & \multicolumn{1}{|c|}{ Inklusi } \\
\hline Jangka Waktu & $\begin{array}{l}\text { Penerbitan jurnal bulan Januari 2019 sd } \\
\text { Desember 2020 }\end{array}$ \\
\hline Subjek & LKPD \\
\hline Bahasa & Bahasa Indonesia \\
\hline Jenis Jurnal & Artikel penelitian, fulltext pdf \\
\hline Tema & Pengembangan LKPD di SMP \\
\hline
\end{tabular}

5. Penelusuran Artikel : Berdasarkan hasil penelusuran di google search dan google scholar dengan kata kunci pengembangan LKPD, pembelajaran IPA, dan keterampilan proses. Ditemukan 240 artikel. Sebanyak 105 artikel dari google search dan 135 artikel dari google scholar. Kemudian dilakukan skrining pengembangan LKPD, di dapat sebanyak 178 artikel, sisanya dieksklusi. Terhadap 178 artikel tersebut dilakukan skrining lagi sesuai mata pelajaran IPA dan tahun diterbitkan sehingga didapatkan 55 artikel, sisanya sebanyak 38 artikel dieksklusi. .Dari 55 artikel yang didapat diskrining lagi sesuai dengan tingkat pendidikan SMP sehingga didapat 17 artikel pengembangan LKPD mata pelajaran IPA SMP tahun 2019-2020, 9 artikel lainnya dieksklusi. Dari 17 artikel yang didapat dilakukan lagi penilaian kelayakan yaitu bentuk teknik pengembangan LKPD yang dilakukan. Sehingga pada akhirnya didapatkan 8 artikel full text yang akan dilakukan review. Eksklusi dilakukan karena artikel tidak sesuai dengan tema, ada yang tidak full text, ada yang tidak bisa dibuka.

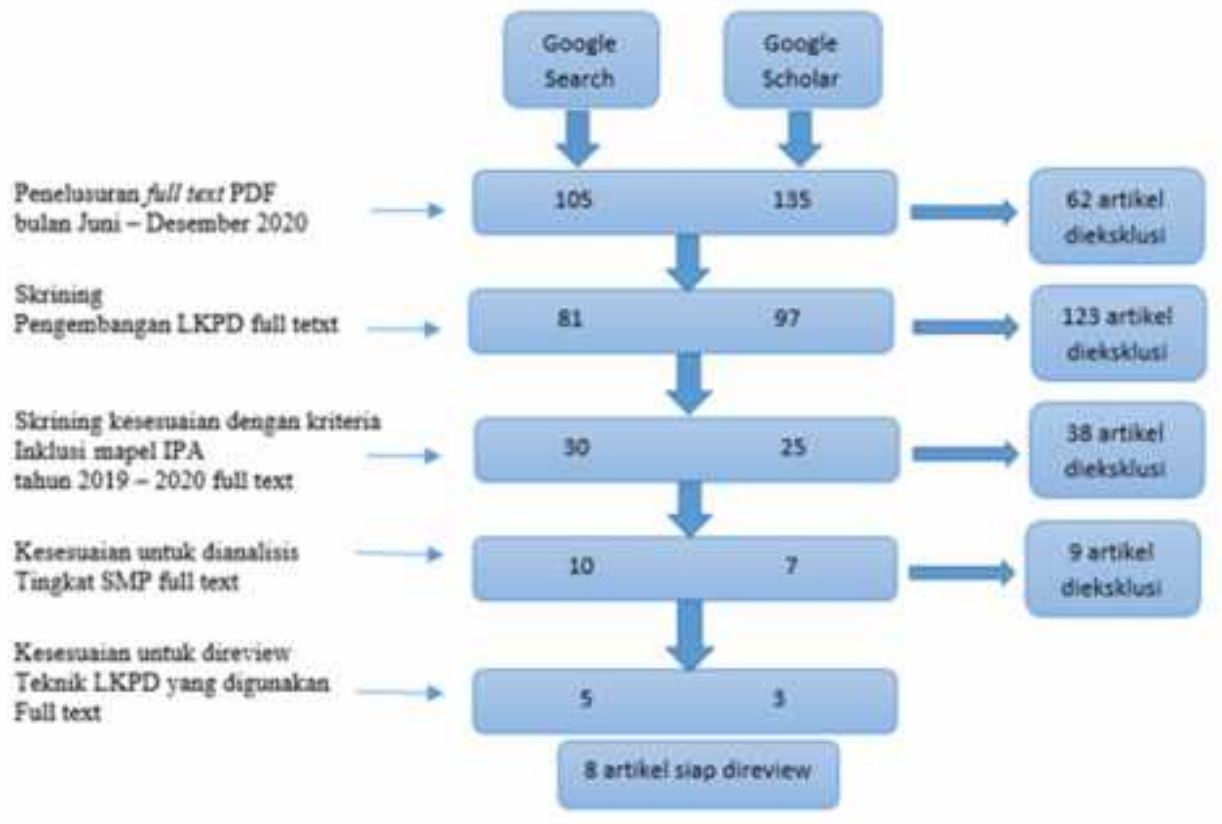

Gambar 1. Diagram Alur Review Artikel

6. Analisis Data : Data yang didapat dianalisis menggunakan metode naratif atau pemaparan. Artikel penelitian yang sesuai dengan kriteria inklusi dikumpulkan dan didata meliputi judul penelitian, nama peneliti, tahun terbit jurnal, metode dan 
ringkasan hasil atau temuan. Ringkasan artikel penelitian tersebut dimasukan ke dalam tabel diurutkan sesuai alphabet dan tahun terbit jurnal dan sesuai dengan format . Untuk lebih memperjelas analisis abstrak dan full text setiap artikel dibaca dan dicermati. Ringkasan artikel tersebut kemudian dilakukan analisis terhadap isi yang terdapat di dalamnya ada tujuan penelitian, metode penelitian, sampel penelitian, dan hasil/temuan penelitian. Data yang sudah terkumpul kemudian dicari persamaan dan perbedaannya lalu dibahas untuk menarik kesimpulan.

\section{HASIL DAN PEMBAHASAN}

Setelah melalui langkah penelusuran pencarian artikel, diperoleh 8 artikel penelitian yang siap dianalisis terhadap isinya. Pada tabel 2 berikut diuraikan judul artikel penelitian, sampel penelitian, dan hasil penelitian. Selanjutnya dilakukan analyzed and compared terhadap ke 8 artikel tersebut.

Tabel 2. Hasil Karakteristik 8 Artikel yang Dipilih

\begin{tabular}{|c|c|}
\hline & \\
\hline 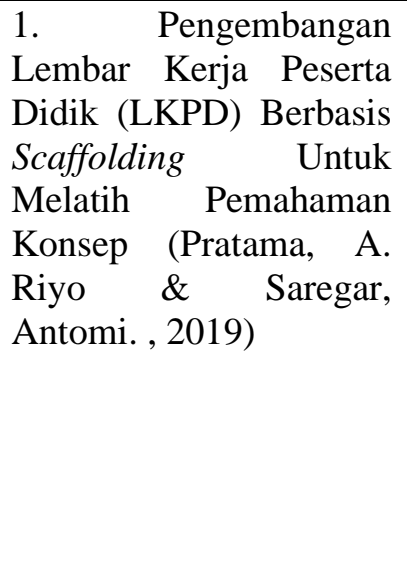 & $\begin{array}{l}\text { arik. } \\
\text { g pada materi kalor memenuhi } \\
\text { as yang sangat layak dan sangat } \\
\text { bagai alternatif media pembelajaran } \\
\text { sebagai sampel adalah dari kelas } \\
\text { li sebanyak } 30 \text { orang, dan peserta }\end{array}$ \\
\hline $\begin{array}{l}2 . \\
\text { LKPD Bengembangan } \\
\text { of Science Uasis } \\
\text { Meniture } \\
\text { Keterampatkan } \\
\text { Sains (Wulan Prondari, Pipit., } \\
\text { Widiyawati, Yeni., \& } \\
\text { Sari, S, Dwi., 2019) }\end{array}$ & KPS peserta didik. \\
\hline $\begin{array}{l}\text { 3. Pengaruh Penera } \\
\text { LKPD Identifikasi Je } \\
\text { Jenis Bambu Terha } \\
\text { Hasil Belajar Pes } \\
\text { Didik Kelas IX S } \\
\text { Bengkulu } \\
\text { (Oktricia, Harya } \\
\text { Yani P Ariefa }\end{array}$ & $\begin{array}{l}\text { nilai } \\
\text { dan } \\
\text { yang } \\
\text { ikasi } \\
\text { aasil }\end{array}$ \\
\hline
\end{tabular}




\begin{tabular}{|c|c|}
\hline & [ B. \\
\hline $\begin{array}{l}4 . \quad \text { Pengembangan } \\
\text { Lembar Kerja Peserta } \\
\text { Didik (LKPD) berbasis } \\
\text { Discovery Learning } \\
\text { Pada Materi Kalor di } \\
\text { SMP (Ariani, Desi \& } \\
\text { Meutiawati, Ida., 2020). }\end{array}$ & $\begin{array}{l}\text { Dengan menggunakan mpdel penelitian ADDIE, } \\
\text { pengembangan LKPD berbasis Discovery Learning yang dinilai } \\
\text { oleh ahli media berada pada kategori layak }(0,80 \pm 0,05) \text { dan } \\
\text { ahli substansi materi juga berada dalam kategori layak }(0,81 \pm \\
0,07) \text {, serta respon peserta didik terhadap LKPD berbasis } \\
\text { discovery learning berada dalam kategori sangat menarik }(0,82 \\
\pm 0,07) \text {. Terjadi peningkatan pemahaman dan hasil belajar } \\
\text { peserta didik pada materi kalor. } \\
\text { Peserta didik yang diambil sebagai sampel adalah kelas VII-2 di } \\
\text { SMP Negeri } 1 \text { Bandar Baru. }\end{array}$ \\
\hline 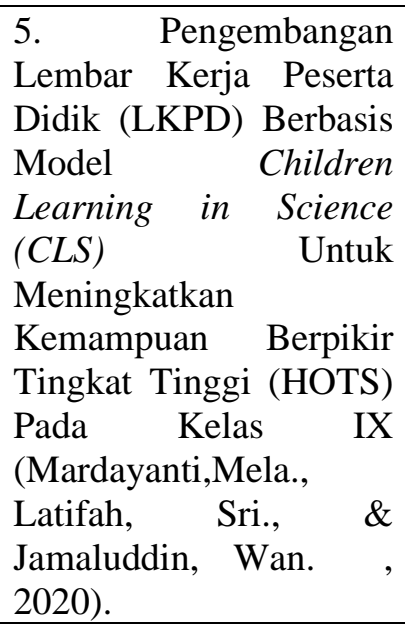 & $\begin{array}{l}\text { Peserta didik yang digunakan sebagai sampel adalah kelas IX } \\
\text { sebanyak } 86 \text { orang dari } 3 \text { sekolah yaitu SMP Negeri } 20 \text { Bandar } \\
\text { Lampung, SMP Negeri } 21 \text { bandar Lampung, dan SMP Negeri } \\
22 \text { Bandar Lampung. }\end{array}$ \\
\hline \begin{tabular}{lr}
\multicolumn{3}{l}{ 6. Pengembangan LKS } \\
IPA SMP Kelas VII \\
Berbasis & Pendekatan \\
Saintifik & Untuk \\
Melatihkan & \\
Keterampilan & Proses \\
IPA Siswa & (Syafi'ah, \\
Rohmatus \& & Laili, M. \\
Alik., 2020).
\end{tabular} & $\begin{array}{l}\text { penelitian 4D, rata-rata } \\
\text { ampilan proses IPA berada } \\
\text { t baik dengan perolehan } \\
\text { ai } 96 \% \text {. Artinya LKS yang } \\
\text { tihkan keterampilan proses } \\
\text { siswa lebih semangat dan } \\
\text { jar mereka. } \\
\text { ii sampel adalah kelas VIII }\end{array}$ \\
\hline $\begin{array}{l}\text { 7. Pengembangan LKPD } \\
\text { Berbasis Group } \\
\text { Investigation Pada } \\
\text { Materi Sistem Tata } \\
\text { Surya (Anggraini, P. } \\
\text { Eka., Kuswanti, Nur., \& } \\
\text { Wijayadi, W. Andri., } \\
\text { 2020) }\end{array}$ & $\begin{array}{l}\text { an model penelitian ADDIE, LKPD IPA } \\
\text { embangkan pada materi Sistem Tata Surya } \\
\text { skor nilai } 3,74 \text { yakni dinyatakan dalam } \\
\text { dalam memahami materi pembelajaran dan } \\
\text { an yang tedapat dalam LKPD. } \\
\text { liambil sebagai sampel adalah kelas VII B } \\
\text { Anwar. }\end{array}$ \\
\hline \begin{tabular}{lr} 
8. LKPD & Berbasis \\
Ngerti, & Ngrasa, \\
Nglakoni (Tri Nga) \\
Untuk Mengembangkan \\
\multicolumn{2}{l}{ Keterampilan Proses }
\end{tabular} & $\begin{array}{l}\text { Dengan menggunakan model penelitian 4D, kualitas LKPD } \\
\text { Keterampilan Proses Sains berbasis Ngerti, Ngrasa, Nglakoni } \\
\text { (Tri Nga) yang dikembangkan menurut penilaian respon peserta } \\
\text { didik secara keseluruhan menyatakan "Sangat Baik" (A) dengan }\end{array}$ \\
\hline
\end{tabular}




\begin{tabular}{|c|c|}
\hline $\begin{array}{l}\text { Sains Kelas VIII SMP } \\
\text { (Rahmawati,V.Erlina., } \\
\text { Ernawati, Tias., \& } \\
\text { Ayuningtyas, D. Annis., } \\
\text { 2020). }\end{array}$ & $\begin{array}{l}\text { skor rata-rata sebesar } 91 \text { yang terletak pada rentang skor } 79,95 \\
\leq X<100 \text {. } \\
\text { perolehan persentase skor pada semua aspek sebesar } 94,2 \% \\
\text { menunjukkan bahwa persentase keidealan keseluruhan yang } \\
\text { diperoleh pada aspek penilaian yang dinilai adalah "Sangat } \\
\text { Baik", dimana peserta didik sangat antusias melakukan kegiatan } \\
\text { pembelajaran. } \\
\text { Peserta didik yang diambil sebagai sampel adalah kelas VIII } \\
\text { SMP Taman Dewasa Ibu Pawiyatan Yogyakarta dan SMP } \\
\text { Neoeri } 2 \text { Godean }\end{array}$ \\
\hline
\end{tabular}

Persamaan yang dapat ditemukan dari literature review terhadap ke delapan artikel tersebut adalah pada tujuan penelitian. Tujuan penelitian menjurus kepada mengembangkan LKPD yang dirancang sendiri oleh guru dikhususkan pada materi pembelajaran IPA tertentu yang disesuaikan dengan kondisi dan karakter peserta didiknya.

Ada persamaan dan perbedaan dalam menggunakan metode dan teknik penelitiannya. Pada artikel penelitian nomor 1, nomor 4 dan nomor 7 sama-sama menggunakan metode RD (Research and Development) dengan mengembangkan model ADDIE (Analysis, Design, Development, Implementation, Evaluation). Sementara itu artikel penelitian nomor 2, nomor5 nomor 6 dan nomor 8 sama-sama menggunakan model 4D yaitu Define (Pendefinisian), Design (Perancangan), Develop (Pengembangan), dan Disseminate (Penyebarluasan). Pada artikel nomor 3 mempunyai metode tersendiri yaitu metode Quasi Experiment (Eksperimen Semu). Secara umum pada artikel penelitian yang mengembangkan model ADDIE hanya melakukan penelitian pada tahap Development (Pengembangan), tidak dilanjutkan pada tahap Implementation dan Evaluation. Demikian pula pada artikel penelitian yang mengembangkan model 4D, hanya melakukan penelitian pada tahap Develop (Pengembangan), tidak dilanjutkan ke tahap Disseminate (Penyebarluasan). Hal ini dilakukan karena memang ada pembatasan tujuan guru dalam merancang LKPD itu sendiri yaitu sebatas mengembangkan LKPD dan menggunakannya pada lingkungan sekolah sendiri. Semua artikel penelitian yang dianalisis sama-sama menggunakan analisis deskripstif kualitatif dan kuantitatif dalam menganalisis data yang dikumpulkan.

Bila ditinjau dari segi hasil secara umum artikel penelitian yang dianalisis menunjukkan hasil yang sama yaitu hasil terbaik dari penelitiannya. Pengembangan LKPD tergolong layak dan valid. Hanya angka persentase kelayakan dan kevalidan saja yang menbedakaannya. Di samping itu LKPD yang dikembangkan benar-benar membangkitkan minat belajar peserta didik serta meningkatkan keterampilan proses peserta didiknya. Hanya saja pada artikel nomor 2 , nomor 3 , nomor 4 , nomor 6 , nomor 7, dan nomor 8, tidak menjelaskan berapa jumlah sampel peserta didiknya. Bahkan pada artikel nomor 2 dan nomor 6 itu sama sekali tidak menjelaskan kelas paralel sampelnya.

Perbedaan artikel yang dianalisis hanya tampak pada keragaman metode pembelajaran yang digunakan dalam kegiatan pembelajarannya. Pada artikel nomor 1 
menggunakan metode pembelajaran berbasis Scaffolding, artikel nomor 2 menggunakan metode pembelajaran berbasis Nature of Science, artikel nomo3 menggunakan metode pembelajaran berbasis eksperimen, artikel nomor 4 menggunakan metode pembelajaran berbasis Discovery Learning $(D L)$, artikel nomor 5 menggunakan metode pembelajaran berbasis Children Learning on Science (CLS), artikel nomor 6 menggunakan metode pembelajaran berbasis pendekatan saintifik, artiekl nomor 7 menggunakan metode pembelajaran berbasis Group Investigation, dan artikel nomor 8 menggunakan metode pembelajaran berbasis Ngerti, Ngrasa, Nglakoni (Tri Nga). Namun semua artikel penelitian pengembangan LKPD yang direview adalah dalam katagori sangat baik dan dapat menjadi bahan acuan bagi guru yang ingin melakukan pengembangan LKPD guna meningkatkan aktifitas dan keterampilan proses peserta didik.

Perbedaan lain juga yang tampak dari sampel penelitiannya. Secara khusus menurut penulis, hasil yang sangat valid tampak pada artikel penelitian nomor 1, nomor 5 , dan nomor 8, karena sampel yang digunakan menggunakan peserta didik pada 2 - 3 sekolah yang berbeda. Sementara pada artikel penelitian lain tidak demikian. Bahkan ada yang sampelnya hanya pada satu kelas, dimana menurut penulis hal tersebut cukup mengurangi kevalidan karena hasil yang dicapai hanya merujuk pada kelas tunggal.

Guru dan peserta didik adalah komponen yang diperlukan dalam proses pembelajaran, dan memiliki peran sangat penting untuk mencapai keberhasilan proses pendidikan. Guru membimbing peserta didik dengan memanfaatkan secara optimal sarana dan media pembelajaran yang tersedia. Di samping itu guru diharapkan terus berkreasi dalam merancang suatu pembelajaran. Begitu pula dalam memilih sumber belajar, menentukan alat dan media belajar yang sesuai dalam kegiatan pembelajaran. Guru diharapkan mampu merancang dan mengembangkan sendiri LKPD dalam pembelajaran. Menurut Nurmahudina, Siti et al (2019), LKPD yang dirancang guru diharapkan mampu memberdayakan peserta didik dalam melakukan kegiatan pembelajaran, dimana pada akhirnya diharapkan peserta didik akan mendapat pengalaman belajar dalam menemukan konsep, menemukan pengetahuan yang baru dialaminya, terampil mengaplikasikan konsep yang mereka temukan, dan mengembangkan keterampilan proses yang dimilikinya. Pengalaman-pengalaman belajar ini juga dapat menjadikan peserta didik menjadi pembelajar mandiri dalam beraktifitas saintifik seperti yang diharapkan pada kurikulum 2013.

\section{KESIMPULAN}

Secara umum dari ke 8 artikel penelitian yang direview tampak persamaan pada tujuan penelitian dan yang dicapai. Perbedaan hanya tampak pada metode dan teknik yang digunakan serta keragaman metode pembelajaran yang digunakan dalam kegiatan pembelajarannya. Pengembangan model ADDIE (Analysis, Design, Development, Implementation, Evaluation), dan model 4D (Define, Design, Develop, Disseminate) banyak digunakan dalam penelitian pengembangan LKPD. Pemilihan metode pembelajaran dalam kegiatan pembelajarannya juga sangat mendukung hasil yang dicapai, LKPD yang dikembangkan benar-benar membangkitkan minat belajar peserta didik serta meningkatkan keterampilan proses peserta didiknya. Semua artikel 
penelitian pengembangan LKPD yang direview adalah dalam katagori sangat baik, tergolong layak dan valid serta dapat menjadi bahan acuan bagi guru yang ingin melakukan pengembangan LKPD guna meningkatkan aktifitas dan keterampilan proses peserta didik.

Secara khusus menurut penulis, hasil yang sangat valid tampak pada artikel penelitian nomor : 1 - Pengembangan Lembar Kerja Peserta Didik (LKPD) Berbasis Scaffolding Untuk Melatih Pemahaman Konsep (Pratama, A. Riyo \& Saregar, Antomi , 2019) , 5 - Pengembangan Lembar Kerja Peserta Didik (LKPD) Berbasis Model Children Learning in Science (CLS) Untuk Meningkatkan Kemampuan Berpikir Tingkat Tinggi (HOTS) Pada Kelas IX (Mardayanti, Mela., Latifah, Sri., \& Jamaluddin, Wan., 2020), dan 8 - LKPD Berbasis Ngerti, Ngrasa, Nglakoni (Tri Nga) Untuk Mengembangkan Keterampilan Proses Sains Kelas VIII SMP (Rahmawati, V.Erlina., Ernawati, Tias., \& Ayuningtyas, D. Annis., 2020), karena sampel yang digunakan menggunakan peserta didik pada 2 - 3 sekolah yang berbeda. Sementara pada artikel penelitian lain tidak demikian. Bahkan ada yang sampelnya hanya pada satu kelas, dimana menurut penulis hal tersebut cukup mengurangi kevalidan karena hasil yang dicapai hanya merujuk pada kelas tunggal.

\section{DAFTAR PUSTAKA}

Anggraini, P. Eka., Kuswanti, Nur., Wijayadi \& W. Andri. (2020). Pengembangan

LKPD Berbasis Group Investigation Pada Materi Sistem Tata Surya. e-Jurnal Ed-Humanistics Vol 5 No 2 diakses 30 November 2020. http://ejournal.unhasy.ac.id/index.php/ed-humanistics/article/view/1066, from DOI : https://doi.org/10.33752/ed-humanistics.v5i2.1066,

Ariani, Desi \& Meutiawati, Ida. (2020). Pengembangan Lembar Kerja Peserta Didik (LKPD) berbasis discovery learning pada materi kalor di SMP. Jurnal Phi: Jurnal Pendidikan Fisika dan Fisika Terapan. Vol 1 No 3 Tahun 2020; ISSN: 2549-7162 Hal.13-19, diakses 3 Maret 2020. https://jurnal.arraniry.ac.id/index.php/jurnalphi/article/view/6477 from

DOI: http://dx.doi.org/10.22373/p-jpft.v1i1.6477

Kemendikbud (2013). Permendikbud nomor 65 tahun 2013 Tentang Standar Proses

Penidikan Dasar dan Menengah. 4 Juni 2013.

Mardayanti, Mela., Latifah, Sri., \& Jamaluddin, Wan. (2020). Pengembangan Lembar Kerja Peserta Didik (LKPD) Berbasis Model Children Learning in Science (CLS) Untuk Meningkatkan Kemampuan Berpikir Tingkat Tinggi (HOTS) Pada Kelas IX. e-Jurnal Inovasi Pembangunan Vol 8 No 01 Tahun 2020. http://journalbalitbangdalampung.org. P-ISSN 2354-5704 e-ISSN 2622-190x. from DOI : http://doi.org/10.35450/jip.v8i01.178

Nurmahudina, Siti., Distrik, W.I., \& Wahyudi, Ismu. (2019), Pengaruh Penggunaan Lembar Kerja Peserta Didik (LKPD) Berbasis Exclusive pada Pembelajaran Alat Optik Terhadap Kemampuan Berpikir Kreatif. Jurnal Tarbawi: Jurnal Ilmu Pendidikan Vol 15 No 02 , Desember 2019 pp 129-139, p-ISSN:1858- 
1080|e-ISSN:2615-6547from

DOI: https://doi.org/10.32939/tarbawi.v15i02.347

Oktricia, Haryani., Yani, P, Ariefa., \& Ansori, Irwandi. (2019). Pengaruh Penerapan LKPD Identifikasi Jenis-Jenis Bambu Terhadap Hasil Belajar Peserta Didik Kelas IX SMP Bengkulu Utara. Diklabio Jurnal Pendidikan dan Pembelajaran Biologi Vol 3 No 2 hal 166-173 tahun 2019. e-ISSN 2598-9669. diakses November 2019. https://ejournal.unib.ac.id/index.php/jppb/article/view/5434. From DOI : 10.33369/diklabio.3.2.166-173.

Pratama, A.Riyo \& Saregar, Antomi. (2019). Pengembangan Lembar Kerja Peserta Didik (LKPD) Berbasis Scaffolding Untuk Melatih Pemahaman Konsep. Indonesian Journal of Science and Mathematics Education Vol 2 No 1 Tahun 2019. ISSN

2615-8639. https://ejournal.radenintan.ac.id/index.php/IJSME/index, from DOI : 10.24042/IJSME.V2I1.3975 Diakses 29 Maret 2019

Rahmawati, V.Erlina., Ernawati, Tias., \& Ayuningtyas, D. Annis. (2020). LKPD Berbasis Ngerti, Ngrasa, Nglakoni (Tri Nga) Untuk Mengembangkan Keterampilan Proses Sains Kelas VIII SMP. e-Jurnal JIPVA-Jurnal Pendidikan IPA Veteran Vol 4 No 2 Desember 2020, http:/lejournal.ivet.ac.id/index.php/jipva/article/view/1186, from DOI : https://doi.org/10.31331/jipva.v4i2.1186 , diakses 18 Desember 2020

Riadi, Muhlisin (2015). Lembar Kerja Peserta Didik (LKPD). e-Jurnal Kajian

Pustaka.com https://www.kajianpustaka.com/2015/07/lembar-kerja-pesertadidik-lkpd.html. diakses 03 Juli 2015

Syafi' ah, Rohmatus \& Laili, M. Alik. (2020). Pengembangan LKS IPA SMP Kelas VII Berbasis Pendekatan Saintifik Untuk Melatihkan Keterampilan Proses IPA Siswa. Lensa (Lentera Sains): Jurnal Pendidikan IPA Volume 10, Nomor 2, halaman 104-113, tahun 2020. http://jurnallensa.web.id/index.php/lensa . from DOI: http://10.24929/lensa.v10i2.115, diakses November 2020

Syafridawaty (2020). Literature Review. e-Jurnal Universitas Raharja. http://raharja.ac.id.2020/10/13.literature-review, diakses 13 Oktober 2020

Wulandari, Pipit., Widiyawati, Yeni., \& Sari, S, Dwi. (2019). Pengembangan LKPD Berbasis Nature of Science Untuk Meningkatkan Keterampilan Proses Sains. e-Jurnal (CSaintifika, Vol.21, No.2, hal.23-34, tahun 2019. https://jurnal.unej.ac.id/index.php/STF/article/view/13562, from DOI : https://doi.org/10.19184/saintifika.v21i2.13562, diakses Juli 2019 